College of Science and Technology in South Kensing. ton. The Plant Engineering and Energy Division is based at the Association's Battersea Research Station, as are the Physics, Chemistry and Operational Research Departments, and there is also a laboratory at Swansea, in the South Wales tinplate area, where some of the Mechanical Working Division's research into sheet and strip manufacture is conducted. The Association's headquarters are at 11 Park Lane, London, W.1.

\title{
THE INTERNATIONAL COUNCIL FOR BIRD PRESERVATION
}

T HE seventh Conference of the European Continental Section of the International Council for Bird Preservation was held in Stavanger, Norway, during June 19-24, and was attended by representatives of the National Sections of Austria, Belgium, Denmark, France, Germany, the Netherlands, Norway, Sweden, Switzerland and the United Kingdom, together with representatives of the International Wildfowl Research Bureau, Conseil International de la Chasse, International Union of Biological Sciences, and the International Union for the Conservation of Nature and Natural Resources.

The destruction of sea birds by waste oil has become a permanent item on the agenda of all conferences of the International Council, and it was noted with great satisfaction that Poland had ratified the International Convention for the Pollution of the Sea by Oil, and that the U.S. Senate had voted 92-0 to ratify this convention. The adhesion of Poland to the convention is of particular importance to Scandinavian countries for it now only requires the support of the U.S.S.R. to enable steps to be taken to declare the whole of the Baltic a prohibited zone for discharge of oil. The area in the Baltic in which oil discharge is now permitted has resulted in heavy pollution, particularly on the coasts of Sweden, where it has caused such great destruction of the long-tailed duck (Clangula hyemalis) that it is feared the status of this species is endangered. The representatives of the Netherlands, where systematic counts of birds killed by waste oil are carried out throughout the year, reported that there were distinctly less than before, and this statement was also supported from Belgium.

A resolution was adopted welcoming the decision of the Inter-Governmental Maritime Consultative Organization to convene, in the spring of 1962, a further conference on oil pollution of the sea, and urging that priority be given to the complete avoidance, at the earliest possible date, of discharge of persistent oils into the sea, and to the immediate provision of adequate facilities for the disposal of oily wastes at refineries, ports of loading and ports of discharge. The resolution further urged National Sections to press their Governments to instruct their delegates to the Inter-Governmental Maritime Consultative Organization conference in 1962 to support action on these lines.

The prejudice against any bird with a hooked beak dies hard, and though some countries reported an increase in certain species it was generally agreed that birds of prey were still being destroyed on a large scale and many species had critically decreased. The need for education on the valuable part these birds play in the balance of Nature was expressed in a resolution which also recommended that if an examination is required to secure a shooting licence a knowledge of identification of birds of prey should be required, in order that protected species should be distinguished from those allowed to be shot.

The destruction of bird life as a result of the use of pesticides has reached such proportions as to cause grave concern all over Europe, and a resolution was passed requesting Governments to adopt legislation by which all pesticides must be officially tested not only with regard to their effect on noxious animals and plants but also on wild life in general before they are permitted to be sold. Further, that Governments be urged to encourage research on the use of specific pesticides and other methods which limit the destruction of wild life, and to forbid or place drastic restrictions on the use of general pesticides that are dangerous to wild life, wherever effect. ive and less dangerous materials can be made available.

The great increase in herring gulls (Larus argentatus) and the harm these cause to other species, particularly in Germany and the Netherlands, has been a problem for many years. In the Netherlands methods of control have been carried out with great success, the number of breeding pairs in 1959 and 1960 being reduced to almost half that of 1954 . One of the factors in the great increase of this species is the easy availability of food in winter, through fish offal at ports, rubbish dumps, etc. In Denmark there is no problem as all fish offal is collected and used for food in mink farms or for fertilizers.

The present policy of land drainage in certain European countries, whether it be economic or not, presents a serious threat to many species of water and wading birds, and two areas in particular were the subjects of special resolutions. The first, the Marismas of the Guadalquivir in Spain, is the richest area in western Europe for marshland birds, particularly as regards migrating and wintering species. The disappearance of these marshes would mean not only the loss of the main European breeding ground of several rare species but would also have irreparable consequences to the status of migratory marsh birds in many European countries. On June 1 an international delegation of representatives of the International Wildfowl Research Bureau, the International Council for Bird Preservation, and the International Union for the Conservation of Nature and Natural Resources, with the Consejo Superior de Investigaciones Cientificas of Spain was received by the Minister of Education in Madrid to consider the possibility of acquiring an area of the Marismas as a reserve and to establish a biological research station there.

The second area, the Baie de L'Aiguillon (Vendée) on the Atlantic coast of France, with its large expanse of mud flats, provides an exceptionally favourable resting place for migratory birds which breed in northern Europe and rest there on their spring and autumn migration. The project to drain this area, for agricultural purposes of doubtful value, in a 
country where there is no lack of agricultural land is being strongly opposed by both French naturalists and sportsmen and their colleagues in other countries.

The proposals concerning the establishment of Council of Europe machinery for matters concerning nature conservancy and national parks were considered, and the prospect of a closer relationship between the Council of Europe and organizations for conservation of Nature was welcomed.

Among other subjects discussed were the traffic in European birds for cageing, bird protection in schools, the danger of the airgun and the increase of the starling (Sturnus vulgaris).

Prof. Sven Hörstadius (Sweden) was unanimously elected chairman of the European Continental Section in succession to Dr. Bøje Benzon (Denmark), and Dr. Gerth von Rokitansky (Austria), vice-chairman, in succession to Dr. G. A. Brouwer (Netherlands). Prof. S. O. Hörstadius, a former president of the International Union of Biological Sciences, was accorded an honorary degree by the University of Cambridge during the tercentenary celebrations of the Royal Society in 1960, and it may be apt to quote the Orator's citation on this occasion:

"We read in Lucretius these lines about the origin of animals: 'And many monsters also did the earth then try to ereate, springing up with strange face and limbs'. She did so to no purpose. But this man does the same to very good purpose. For beginning his studies from the egg in no mere proverbial sense, and using incredible penetration of mind and dexterity of hands alike, he has taken to pieces, down to their smallest components, the embryos of sea-urchins, worms and amphibia, and then re-assembled these into new animal organisms. Would anyone have believed before that two tissues cut from an embryonic newt combined could co-operate to form cartilage, and that, with the addition of a third, tooth would result ? What wonderful metamorphoses, and advantageous indeed to men! For from this he has thrown light on the influence of part upon part and organ upon organ in the gradual construction of the adult animal, which could be of great value to the art of medicine. So we salute one who has at last set foot on the true way in an inquiry raised by Aristotle himself.

"But do not imagine he only examines and handles eggs. For he is an observer of the ways of birds, and in that most pleasant branch of study also has won world-wide fame.

"I present to you a professor of Uppsala, worthy heir of the studies of Linnæus of Uppsala-Sven Otto Hörstadius".

Phyllis Barclay-Smith

\section{IMMUNITY TO PROTOZOA}

$\mathrm{I}_{\text {of }}^{\mathrm{N}}$ $\mathrm{N}$ the age of Metchnikow and Ehrlich, the subject of immunity had not become divided into the separate compartments of bacteria, fungi, protozoa, etc., as it has to-day, and a broader view was possible at that time. A recent symposium, organized by the British Society for Immunology at the Middlesex Hospital during June 1-2, represented an attempt by the Society to reverse the trend and to bring workers of one specialized field (protozoology) into the classical milieu. Various aspects of immunity to protozoa were thus presented, and, to some extent the idea of the Society was successful, many interesting papers were given, and these provoked some discussion.

The subject of the symposium, "Immunity to Protozoa", was introduced by P. C. C. Garnham, who gave a short historical survey, then a summary of the histological basis of immunity and finally a review of acquired and innate immunity in the parasitic protozoa. In his opinion, the realm of innate or natural immunity offered at present the most promising opportunities for research. All degrees of resistance of the host to the organism are found, which may be influenced by various internal factors like unsuitable blood components (later ably described by A. C. Allison in regard to the inhibitory action of sickle-cell hæmoglobin and glucose-6dehydrogenase deficiency on Plasmodium falciparum), by external factors like removal of the spleen, and lastly by the site occupied by the parasite in relation to its host: immunity thus may be unable to touch the parasite when it is safely enclosed within a paren. chyma cell of the liver, yet immunity will kill rapidly when it lies in an exposed position in the blood stream.

The symposium was honoured by the presence of Edmond Sergent, who came from Algiers to give a lucid account of premunition, a subject which has occupied him for the past 60 years and which he here crystallized into 26 precise definitions. Premunition is the basis of the subject, and yet has been much misunderstood; it was useful to have it described by the Martre himself. On the other hand, premunition is not the only form of immunity, and A. Corradetti deseribed examples of true residual immunity in rats which had recovered from Plasmodium berghei and Trypanosoma lewisi infections respectively; in some cases, nothing could break down this resistance, and he clearly showed that the protozoa had been completely eliminated by the immunity response, while the rats proved to be immune for life.

Much of the original work on the cellular basis of immunity was carried out by W. H. Taliaferro, by his wife Lucy, and his collaborator, H. Mulligan. All these workers were present at the symposium, and the subject was introduced by W. H. Taliaferro, who described briefly the lymphoid-macrophage system and then went on to more recent work of a biochemical nature. This indicated that under the influence of the growth-inhibitory antibody, 'ablastin', nucleic acid synthesis in T. lewisi comes to a stop, although protein synthesis may continue at a low level. He also considered the phenomenon of 'avidity' or antigen-binding capacity. His explanation of the development of immunity in $T$. lewisi infections by the successive appearance of several different types of antibody was challenged by W. E. Ormerod, who suggested that the disappearanee of young and dividing forms (the earliest of which inhabit the protected environment of the kidney capillaries) was not due to 'ablastin' but to an ordinary type of antibody which had a selective action on the young forms.

The subject of immunity cannot properly be considered apart from the nature of the damage inflicted 